\title{
Smectite Clay Modified with Quaternary Ammonium as Oil Remover
}

\author{
Carlos A. Lira Junior, ${ }^{a, b}$ Domingos S. A. Silva, ${ }^{c}$ Arão P. da Costa Filho, ${ }^{c}$ \\ Elizabete F. Lucas ${ }^{c}$ and Sirlane A. A. Santana ${ }^{*, b}$ \\ ${ }^{a}$ Departamento de Ensino Superior e Tecnologia, Instituto Federal do Maranhão, Campus Bacabal, \\ Avenida João Alberto, s/n, 65700-000 Bacabal-MA, Brazil \\ ${ }^{b}$ Departamento de Química and ${ }^{c}$ Departamento de Tecnologia Química, Universidade Federal do \\ Maranhão, Avenida dos Portugueses, 1966, Cidade Universitária, 65080-805 São Luis-MA, Brazil \\ ${ }^{c}$ COPPE/PEMM, Universidade Federal do Rio de Janeiro, Avenida Horacio Macedo, 2030, bloco F, \\ Cidade Universitária, 21941-598 Rio de Janeiro-RJ, Brazil
}

\begin{abstract}
Clays such as smectite have high technical and economic viability due to their large adsorption capacity. These properties can be improved by treatment with acids or other modifications. This paper describes experiments to prepare and characterize organoclays and to evaluate their ability to remove oil from contaminated water in comparison with clay in its natural state. We used natural smectite clay from the municipality of Presidente Dutra, Maranhão State, modified with the quaternary ammonium salt cetyltrimethylammonium bromide. Characterization was performed by X-ray diffraction, Fourier transform infrared spectroscopy, X-ray fluorescence, thermogravimetry and determination of surface area by the Brunauer-Emmett-Teller (BET) method. The results showed appropriate conditions of the organophilization process, indicating the intercalation of quaternary ammonium cations between the clay layers. The adsorption tests showed that the natural clay reduced the amount of oil contained in the aqueous medium by $76.16 \%$, while the corresponding removal rates of all organoclays tested were above $92 \%$, which makes them potentially applicable to remove oil from wastewaters.
\end{abstract}

Keywords: smectite, organophilization, quaternary ammonium, adsorption, oily water treatment

\section{Introduction}

Petroleum is a complex mixture of various organic compounds, principally hydrocarbons, along with other constituents such as sulfur, nitrogen, oxygen and metals. Petroleum and its derivatives are the world's main source of energy but also are one of the main sources of environmental pollution. ${ }^{1-4}$ During the process of extracting crude oil, a considerable quantity of water is found mixed with the oil. This produced water needs to be treated before being discharged or reused in the production process or in other areas. ${ }^{5,6}$

Interest in developing better treatment methods has grown in recent years as environmental regulations applicable to the production, transport and storage of petroleum have become more stringent. ${ }^{7.8}$ The concentration of contaminants in industrial effluents in general can be

*e-mail: saa.santana@ufma.br reduced by various physical and/or chemical processes, including chemical and catalytic oxidation, biological techniques, electrolytic methods, adsorption and membrane filtration. ${ }^{5,9-12}$ Of these, adsorption is one of the most promising methods. ${ }^{6}$

Adsorption has been widely studied and used to treat effluents contaminated by various toxic substances. ${ }^{13-22}$ Natural adsorbents such as clays can be chemically modified to adjust their physical-chemical properties, adding functionalities for use in various types of applications. ${ }^{10,23,4}$ Specifically in the treatment of effluents produced by the petroleum industry, it is important to develop new materials and improve existing ones that have good cost-benefit ratios, especially those that are abundant in nature.

Various materials can be used to remove oil from contaminated water, such as adsorbents like activated charcoal, clays, deposited carbon, leaves, ceramic beads, wool fibers and polymer resins. Deposited carbon and 
activated charcoal stand out for their high specific surface area, with values between 500 and $1500 \mathrm{~m}^{2} \mathrm{~g}^{-1}$, permitting good adsorption capacity. ${ }^{6,25-27}$ Despite these advantages, their generalized use is restricted by their high production cost, leading to the search for alternative adsorbents. Clays are attractive because of their low cost and high adsorption potential. ${ }^{28}$ Besides removing oil, clays also serve as adsorbents of heavy metals, dyes and other contaminants. ${ }^{29-32}$

Natural clays are hydrophilic compounds, often making them unsuitable as adsorbents of organic compounds. However, modification with organic molecules intercalated between their structural layers makes them hydrophobic, enabling their use to remove organic compounds. Clays subjected to this modification are called organophilic. ${ }^{33,34}$

The clay used in this paper is characterized as smectite from igneous rock, usually a volcanic tuff or ash. In the group of phyllosilicate clay mineral, montmorillonite, beidelita, nontronite, saponite and hectorite are the most important. Montmorillonite is the most abundant and its properties allow its application in several industrial areas. The general chemical formula is $\mathrm{M}^{\mathrm{x}}\left(\mathrm{Al}_{4-\mathrm{x}} \mathrm{Mg}_{\mathrm{x}}\right) \mathrm{Si}_{8} \mathrm{O}_{20}(\mathrm{OH})_{4}$, where $\mathrm{M}^{\mathrm{x}}$ represents alkali and alkaline earth metals in interlamellar layers. Such metals are also called changeable cations, since they can be changed by other cations under reversible way. ${ }^{35-38}$

The smectite plates present irregular shape, are very thin and tend to aggregate during drying. Its basic structure has negatively charged surface that is neutralized by the changing cations which are on their sides and, mainly, between their lamellas, known as interplanar space. In this region, the water molecules are adsorved and the changing cations (as $\mathrm{Ca}^{2+}, \mathrm{Mg}^{2+}, \mathrm{Na}^{+}$) are electrostatically fixed, having the function of compensating negative charges generated by isomorphic replacing in the network. 37,39,40 The predominance of one of these cations and the clay mineralogy will determine its properties, such as expansion and cation exchange. ${ }^{36-38,41-43}$

Natural clays can be modified according to their cation exchange capacity (CEC), which is the quantity of exchangeable cations per dry weight. This exchange is of great interest because it alters the basal interplanar distance, enhancing the adsorption capacity. The exchangeable cations, which are connected electrostatically along the faces and allocated between the structural layers, are grouped according to their facility for substitution or exchange in the following order: $\mathrm{Li}^{+}>\mathrm{Na}^{+}>\mathrm{K}^{+}>\mathrm{Rb}^{+}>$ $\mathrm{Cs}^{+}>\mathrm{Mg}^{2+}>\mathrm{Ca}^{2+}>\mathrm{Sr}^{2+}>\mathrm{Ba}^{2+}>\mathrm{H}_{3} \mathrm{O}^{+} .{ }^{44}$ Besides valence, the exchange capacity is related to hydration, so that the lower the valence and the greater the hydration, the greater the exchange capacity will be. ${ }^{45}$
Organophilic clays can be prepared by substituting the cations located between the layers with quaternary ammonium salts, which have four organic radicals linked to nitrogen by covalent bonds and a positive charge, neutralized by an anion. ${ }^{46,47}$

In this study we used a clay that is abundant in the state of Maranhão, Brazil, in its natural state and modified by incorporation of cetyltrimethylammonium bromide (CTAB) to obtain materials with high functionalization degree. We characterized the resulting compounds to elucidate the mechanisms involved in their formation and assessed them for their capacity to remove oil from contaminated water, under various experimental conditions.

\section{Experimental}

\section{Materials}

The clay used in this work was obtained from the municipality of Presidente Dutra, Maranhão State, and had not undergone any industrial treatment process. The quaternary salt used was cetyltrimethylammonium bromide (CTAB), supplied by ISOFAR, with purity of $98.0 \%$.

\section{Preparation of the natural clay}

The natural clay samples were cleaned manually to remove impurities like pebbles, leaves, etc. Then the clay was washed with distilled water and screened through a sieve with mesh of $0.18 \mathrm{~mm}$ to remove other smaller impurities. Next, the suspension containing the clay was left at rest for $24 \mathrm{~h}$, after which the supernatant was separated and the clay was dried in an oven at $105^{\circ} \mathrm{C}$ for $24 \mathrm{~h}$. The dried clay was then ground with a mortar and pestle and sifted to obtain grain size between 25 and $75 \mu \mathrm{m}$. The resulting material was used to produce the modified materials.

\section{Determination of the cation exchange capacity (CEC)}

The CEC was determined using barium chloride buffered with triethanolamine- $\mathrm{BaCl}_{2}$-TEA, as described by Mehlich. ${ }^{48}$ In this process, $40 \mathrm{~mL}$ of the triethanolamine (TEA) buffer solution at $0.338 \mathrm{~mol} \mathrm{~L}^{-1}$ and $\mathrm{BaCl}_{2}$ $1.000 \mathrm{~mol} \mathrm{~L}^{-1}$ at $\mathrm{pH} 8.2$ was added to $1 \mathrm{~g}$ of natural clay and this mixture was kept at $170 \mathrm{rpm}$ for 16 hours, being, after that, centrifuged. Then, $20 \mathrm{~mL}$ of a solution of $\mathrm{MgSO}_{4} .7 \mathrm{H}_{2} \mathrm{O} 0.025 \mathrm{~mol} \mathrm{~L}^{-1}$ was added. Then $0.5 \mathrm{~mL}$ of the buffer solution $\mathrm{NH}_{4} \mathrm{OH} / \mathrm{NH}_{4} \mathrm{Cl}, \mathrm{pH}=10$, was added to the supernatant and the solution was titrated with $\mathrm{Na}_{2}$ EDTA $0.01 \mathrm{~mol} \mathrm{~L}^{-1}$ along with the indicator eriochrome black $\mathrm{T}$. 


\section{Preparation of the organophilic clay}

To obtain the organophilic clay, a suspension containing $25 \mathrm{~g}$ of clay and $500 \mathrm{~mL}$ of deionized water was mixed with a solution of CTAB, under stirring at $200 \mathrm{rpm}$ for $3 \mathrm{~h}$. The CTAB was prepared by adding a mass of the surfactant (corresponding to 50,100 or $150 \%$ of the clay's CEC) in $100 \mathrm{~mL}$ of deionized water, after which the solution was stirred for $30 \mathrm{~min}$. Then the clay was washed with deionized water and vacuum filtered until the conductivity of the supernatant remained constant, a parameter necessary for removal of the excess bromide ions. Then the material was dried in an oven at $105{ }^{\circ} \mathrm{C}$ for $24 \mathrm{~h}$ and ground into powder.

To check the effect of temperature during preparation of the organophilic clay, the aqueous dispersions of clay and salt were prepared at temperatures of 25,55 and $75^{\circ} \mathrm{C}$. For the adsorption testing and other characterizations, the natural clay and the three organophilic clays that presented the greatest basal spacings were used, as determined by $\mathrm{X}$-ray diffraction.

\section{Characterization of the clay materials}

The samples of natural clay and clay modified with CTAB salt were characterized by X-ray diffraction (XRD), $\mathrm{X}$-ray fluorescence (XRF), Fourier transform infrared spectroscopy (FTIR), thermogravimetric analysis (TG) and measurement of specific surface area and pore diameter.

The samples were screened through sieves with mesh sizes between 25 and $75 \mu \mathrm{m}$, pressed on acrylic supports and analyzed in scanning mode with a Bruker D8 Advance diffractometer, with $\mathrm{K} \alpha$ radiation of $\lambda 0.0154056 \mathrm{~nm}$, produced by a copper tube, at $40 \mathrm{kV}$ and $40 \mathrm{~mA}$, with scanning amplitude of $2 \theta$ per minute $\left(0.04^{\circ} \mathrm{s}^{-1}\right)$ from $3^{\circ}$ to $90^{\circ}$.

The chemical elements present in the samples were quantified by X-ray fluorescence by direct analysis of pellets with diameter of $18 \mathrm{~mm}$ containing approximately $500 \mathrm{mg}$ of each sample, using a Rigaku RIX 3100 XRF spectrometer equipped with a rhodium tube.

The FTIR spectra of the samples were obtained with a PerkenElmer 2000 spectrometer in the spectral range from 4000 to $400 \mathrm{~cm}^{-1}$, using $\mathrm{KBr}$ pellets.

The curves of mass loss in function of temperature were obtained with a Shimadzu TGA-51 analyzer under flow of $20 \mathrm{~mL} \mathrm{~min}^{-1}$ of $\mathrm{N}_{2}$, with reading in the temperature range from 25 to $900{ }^{\circ} \mathrm{C}$ at a heating rate of $10{ }^{\circ} \mathrm{C} \mathrm{min}$.

The surface area and average pore diameter of the samples were determined, respectively, by the methods of Brunauer-Emmett-Teller (BET) and Barret-Joyner-Halenda
(BJH). ${ }^{49,50}$ For this purpose, we used a Quantachrome Instruments NOVA 4200 instrument to measure the physical adsorption of nitrogen in the samples, after degasification for $4 \mathrm{~h}$ at $195^{\circ} \mathrm{C}$.

Preparation of the synthetic oily water

The synthetic oily water was prepared from a dispersion of crude oil in a saline solution containing total salts of $55,000 \mathrm{ppm}\left(\mathrm{NaCl}: \mathrm{CaCl}_{2}\right.$ 10:1) under rotation of 10,000 rpm for 10 minutes, in an Ultra-Turrax homogenizer. ${ }^{17}$ The prepared solutions had average oil concentration of $50 \mathrm{ppm}$.

\section{Adsorption evaluation}

Two types of adsorption tests were performed. The first consisted of varying the mass of the adsorbent (natural and organophilic clay samples), with the contact time and oil concentration in the saline solution held constant. The second consisted of varying the contact time while keeping the adsorbent mass and oil concentration fixed.

\section{Variation of adsorbent mass}

In this test, an absorbent mass of $0.1,0.3,0.7$ or $1.0 \mathrm{~g}$ was placed in $50 \mathrm{~mL}$ of oily water for $4 \mathrm{~h}$ at $25^{\circ} \mathrm{C}$ under stirring of $100 \mathrm{rpm}$. After the contact time, the samples were centrifuged for $10 \mathrm{~min}$ at $4000 \mathrm{rpm}$ and the total oil and grease (TOG) content of the supernatant was measured.

\section{Variation of contact time}

In this test, $1 \mathrm{~g}$ of adsorbent was placed in $50 \mathrm{~mL}$ of oily water, in a thermostatically controlled bath at a temperature of $25^{\circ} \mathrm{C}$, with stirring of $100 \mathrm{rpm}$, for times of $15,30,60$, 120,180 and $240 \mathrm{~min}$. Then the samples were centrifuged for $10 \mathrm{~min}$ at $4000 \mathrm{rpm}$ and the TOG was determined.

\section{Determination of the total oil and grease content (TOG)}

After centrifugation, a $45 \mathrm{~mL}$ aliquot of oily water was placed in a $100 \mathrm{~mL}$ test tube and mixed with $5 \mathrm{~mL}$ of $n$-hexane. The system was shaken manually for about 2 minutes to extract the largest possible quantity of the oil phase to the medium containing $n$-hexane. After complete separation, the organic phase (containing oil and grease) at the top of the tube was extracted and transferred to a cuvette for reading in a Turner Designs TD3100 spectrofluorometer, previously calibrated with two solutions: pure $n$-hexane and oily water with concentration of $225 \mathrm{mg} \mathrm{L}^{-1}$. The TOG concentration in ppm was then read directly by the device. 


\section{Results and Discussion}

Cation exchange capacity (CEC)

The CEC value for the clay was 85 meq per $100 \mathrm{~g}$, a value in line with those of smectitic materials, of 70 to 150 meq per 100 g. ${ }^{51}$

X-Ray diffraction (XRD)

Figure 1 presents the X-ray diffractogram of the untreated clay. Characteristic peaks can be observed for clay that has smectite as the predominant mineral. ${ }^{48,51}$ The first peak, that appears before $2 \theta$ angle corresponding to $10^{\circ}$, with the value of $5.84^{\circ}$ and so $\theta=2.92^{\circ}$, represents the basal distance $\left(\mathrm{d}_{001}\right)$, determined by Bragg's Law $(\mathrm{d}=\mathrm{n} \lambda / 2 \sin \theta)$, with $\mathrm{n}=1$ and $\lambda=0.154056 \mathrm{~nm}$. The value found was $1.51 \mathrm{~nm}$, in line with other reports in the literature. ${ }^{52-54}$ Such spacing is provoked by small cations and molecules between mineral clay's layers. ${ }^{55-57}$

\section{Effect of CTAB concentration}

The clay mineral used in this study is expansive, thus allowing the interlamellar distance to be increased, depending on the size of the molecule used for modification. ${ }^{58}$ This expansion is measured by the shift of the $d_{001}$ diffraction angle, since according to Bragg's law, this angle is inversely proportional to the interatomic distance. A reduction of this angle indicates interlamellar expansion of the clay mineral.

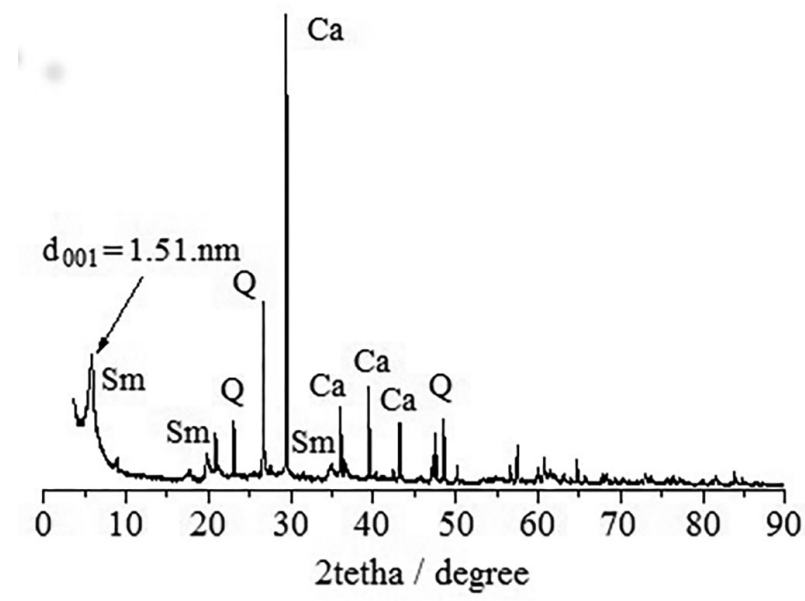

Figure 1. X-Ray diffractogram of natural clay (Q: quartz; Ca: calcite; Sm: smectite).

Figure 2 shows the diffractograms of natural clay and the organophilic clays prepared at $25{ }^{\circ} \mathrm{C}$ with different concentration of CTAB salt $(50,100$ and $150 \%$ of the CEC). The salt incorporation provokes an increasing in the interlamellar space of the clay, reducing the diffraction angle (Figure 2b). Such behavior confirms ion exchange in the clay layers and the achievement of the organophilic clay. The salt did not change the chemical structure of the clay since other peaks have not changed.

\section{Effect of processing temperature}

The results obtained with organophilic clays prepared at 55 and $75^{\circ} \mathrm{C}$, and CEC of 50,100 and $150 \%$, are presented in Table 1 . The data show that the basal spacing increased in all

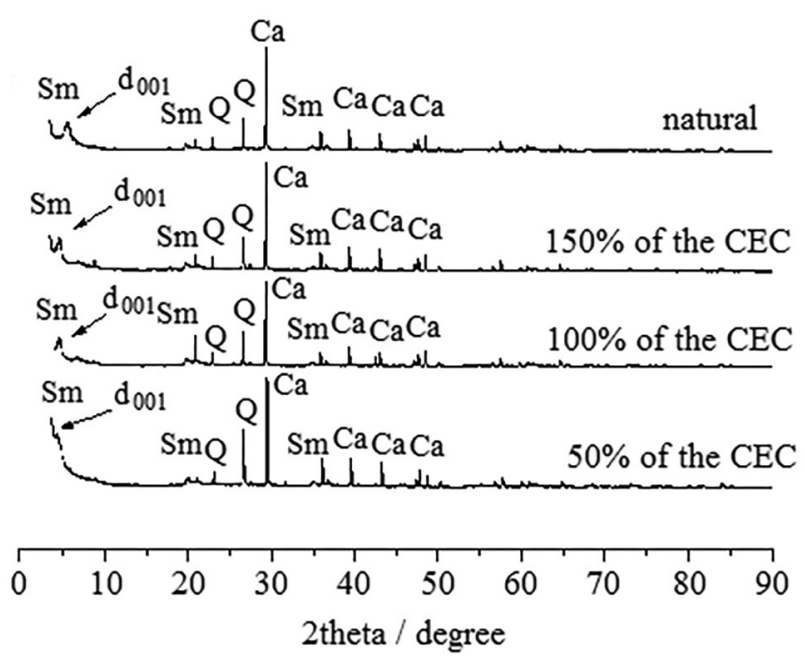

(a)

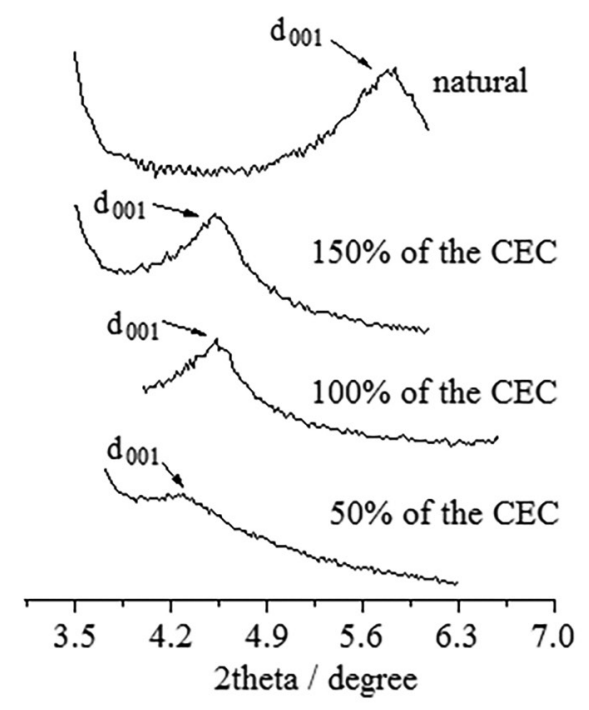

(b)

Figura 2. X-Ray diffractogram of natural clay and organophilic samples prepared with different concentration of CTAB $25^{\circ} \mathrm{C}$ : (a) $2 \theta$ from 0 to $90^{\circ}$ and (b) evidencing the region around $5.0^{\circ}$ (Q: quartz; Ca: calcite; Sm: smectite). 
the organophilic clays produced except Sm50/55 (which did not present $\mathrm{a}_{001}$ peak), in comparison with the natural clay, proving the effective intercalation of the CTAB molecules in the clay. The values indicate a bilayer or pseudo-triple layer arrangement of the clay structures. ${ }^{59}$ Despite containing the lowest quantity of salt, the organophilic clay Sm50/75 presented the largest basal spacing $(2.16 \mathrm{~nm})$ among all the samples. This can be explained because the basal spacing varies according to the orientation of the quaternary ammonium salt used in the modification. .9,60 $^{50}$

Table 1. Basal spacings of the natural and organophilic clay samples

\begin{tabular}{lccc}
\hline $\mathrm{CEC}^{\mathrm{a}}$ & $\begin{array}{c}\text { Preparation } \\
\text { temperature } /{ }^{\circ} \mathrm{C}\end{array}$ & Nomenclature & $\begin{array}{c}\text { Spacing, } \\
\mathrm{d}_{001} / \mathrm{nm}\end{array}$ \\
\hline Natural & - & Natural & 1.51 \\
\hline $50 \%$ & 25 & Sm50/25 & 2.10 \\
& 55 & Sm50/55 & - \\
\hline $100 \%$ & 75 & Sm50/75 & 2.16 \\
\hline & 25 & Sm100/25 & 1.95 \\
& 55 & Sm100/55 & 1.96 \\
$150 \%$ & 75 & Sm100/75 & 1.97 \\
& 25 & Sm150/25 & 1.93 \\
& 55 & Sm150/55 & 1.75 \\
\hline
\end{tabular}

${ }^{\mathrm{a}}$ Cation exchange capacity.

The preparation temperature influenced the samples prepared with $150 \%$ of the CEC, so that the basal spacing $\left(\mathrm{d}_{001}\right)$ reduced from $1.93 \mathrm{~nm}$ (when prepared at $25^{\circ} \mathrm{C}$ ) to $1.71 \mathrm{~nm}$ (when prepared at $75^{\circ} \mathrm{C}$ ). For the other samples, the CTAB intercalation was not significantly influenced by temperature. The basal spacing decreased as increasing salt concentration during the organophilic clay preparation. In fact, the temperature and surfactant concentration do not directly influence the basal spacing since it changes in function of CTAB orientation in the interlamellar space..$^{60-62}$

Besides the in natura clay, the organophilic ones E50/75, E100/75 and E150/25 were used for further characterizations and to study the oil removal from water, since they presented the highest values of basal spacing obtained by XRD and Bragg's law.

\section{X-Ray fluorescence (XRF)}

From the X-ray fluorescence analysis it was possible to determine the chemical composition of the four samples. Table 2 reports the percentages of oxides present. The chemical composition of smectite clays varies substantially according to the place where they are obtained, and can even vary in the same deposit. Therefore, comparison of clays of the smectite group is somewhat complicated since there are no defined chemical compositions to serve as a base for reference. However, from the $\mathrm{SiO}_{2} / \mathrm{Al}_{2} \mathrm{O}_{3}$ ratio it is possible to determine to what group a certain clay sample belongs. ${ }^{63}$ This proportion was 3.12 for the untreated clay, confirming it belongs to the smectite group. ${ }^{51}$

Table 2. Chemical composition, in oxides, of the clay samples

\begin{tabular}{lcccc}
\hline \multirow{2}{*}{ Oxide } & \multicolumn{4}{c}{ Chemical composition / \% } \\
\cline { 2 - 5 } & Natural & $\mathrm{Sm} 50 / 75$ & $\mathrm{Sm} 100 / 75$ & $\mathrm{Sm} 150 / 25$ \\
\hline $\mathrm{SiO}_{2}$ & 42.70 & 44.87 & 45.01 & 44.92 \\
$\mathrm{CaO}$ & 28.73 & 26.55 & 26.43 & 26.55 \\
$\mathrm{Al}_{2} \mathrm{O}_{3}$ & 13.74 & 13.87 & 13.83 & 13.81 \\
$\mathrm{Fe}_{2} \mathrm{O}_{3}$ & 7.18 & 7.24 & 6.57 & 6.39 \\
$\mathrm{MgO}$ & 3.48 & 3.01 & 3.07 & 2.99 \\
$\mathrm{~K}_{2} \mathrm{O}$ & 2.36 & 2.44 & 2.22 & 2.22 \\
$\mathrm{Na}_{2} \mathrm{O}$ & 0.06 & 0.06 & 0.05 & 0.06 \\
$\mathrm{Br}$ & - & 0.25 & 1.24 & 1.51 \\
Others & 1.76 & 1.69 & 1.57 & 1.55 \\
\hline
\end{tabular}

The treatment caused a reduction in the level of calcium in comparison with the natural clay. This reduction is related to the intercalation of the CTAB molecules and consequent substitution of the $\mathrm{Ca}^{2+}$ present in the clay. The incorporation of CTAB in samples Sm50/75, Sm100/75 and Sm150/25 caused the appearance of bromine (Br), with the concentration increasing with rising quantity of salt used to modify the samples. This can be understood as the residue of the CTAB present in the clay after washing.

\section{Fourier transform infrared spectroscopy (FTIR)}

Figure 3 presents infrared spectra of the natural clay and organophilic clays Sm50/75, Sm100/75 and Sm150/25. Comparison of the spectra shows the presence of peaks at 3630 and $3436 \mathrm{~cm}^{-1}$, which define the bands related to the free and/or combined $\mathrm{OH}$ group. ${ }^{64}$ The presence of $\mathrm{H}_{2} \mathrm{O}$ is confirmed by the absorption at approximately $1630 \mathrm{~cm}^{-1}$, corresponding to the $\mathrm{H}-\mathrm{O}-\mathrm{H}$ angular deformation. The spectra also have peaks at $1025 \mathrm{~cm}^{-1}$, characteristic of asymmetric $\mathrm{Si}-\mathrm{O}$ stretching, $\mathrm{Al}-\mathrm{OH}$ deformation vibrations at $872 \mathrm{~cm}^{-1}$ and $\mathrm{Si}-\mathrm{O}$ and $\mathrm{O}-\mathrm{Al}$ vibrations at 793 and $507 \mathrm{~cm}^{-1}$, respectively. ${ }^{65,66}$ The presence of the same peaks in all samples, except that corresponding to the $\mathrm{H}-\mathrm{O}-\mathrm{H}$ angular deformation, indicates that the structures of the modified clay samples were maintained after organophilic treatment. 
The spectra of the organophilic clays contain a pair of bands between 2851 and $2918 \mathrm{~cm}^{-1}$, which result from asymmetric and symmetric vibrational $\mathrm{C}-\mathrm{H}$ stretching of the $\mathrm{CH}_{3}$ and $\mathrm{CH}_{2}$ groups present in the amine chains. The appearance of these peaks confirms the organophilization of the clay. ${ }^{64,67}$

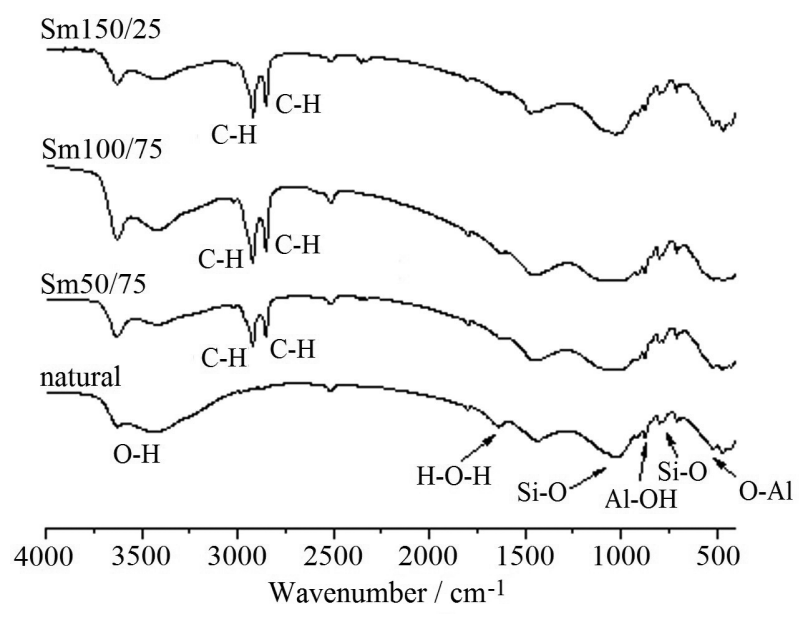

Figure 3. Infrared spectra of the natural and organophilic clay samples.

\section{Thermogravimetric analysis (TG)}

The samples (natural, Sm50/75, Sm100/75 and Sm150/25) were analyzed by thermogravimetry. All curves exhibited three thermal decomposition ranges. The first occurred at a temperature between 15 and $136^{\circ} \mathrm{C}$, where the natural sample presented mass loss of $3.95 \%$ and the organophilic clays Sm50/75, Sm100/75 and Sm150/25 underwent losses of $1.95,1.38$ and $1.26 \%$, respectively, indicating the existence of less free water in the organophilic clays. ${ }^{68,69}$ Between temperatures of 200 and $600{ }^{\circ} \mathrm{C}$, a second thermal decomposition step occurred. In this range, the natural clay lost $1.74 \%$ of its mass, while the organophilic clays Sm50/75, Sm100/75 and Sm150/25 lost approximately 11.0, 16.7 and 20.2\% of their masses, respectively. This greater mass loss can be attributed to the decomposition of the CTAB salt used for organophilization of the samples, with a larger mass loss with higher concentration of that salt ${ }^{29}$

The last decomposition step is attributed to the dehydroxylation of the clay mineral and occurred at a temperature above $700{ }^{\circ} \mathrm{C}$, where there was mass loss of about $12 \%$ in all the samples. ${ }^{68,70}$ Overall, sample Sm150/25 lost the most mass (37.2\%), followed by Sm100/75 and Sm50/75, which lost 32.5 and 30.5\%, respectively. All these losses were greater than for the natural clay, which lost $19.1 \%$ of its mass, indicating effective intercalation of the CTAB salt.

\section{Specific surface area and average pore diameter}

The results of measuring the surface area by the BET method and average pore diameter by the $\mathrm{BJH}$ method are shown in Table 3.

The surface area value of $27.8 \mathrm{~m}^{2} \mathrm{~g}^{-1}$ found for the natural clay is considered low, but this is a characteristic of smectite clays and is in line with the values reported in the literature. ${ }^{16,58,71}$ The organophilization reduced the surface area, due to the aggregation of the quaternary ammonium salts, which prevents the entrance of nitrogen molecules. The results of other studies indicate this tendency is observed most of the time, although the specific surface area of clay can increase after modification. ${ }^{29,59}$

Table 3. Surface area and average pore diameter

\begin{tabular}{lcc}
\hline Sample & Surface area $/\left(\mathrm{m}^{2} \mathrm{~g}^{-1}\right)$ & Pore diameter $/ \mathrm{nm}$ \\
\hline Natural & 27.8 & 1.53 \\
Sm50/75 & 2.85 & 13.04 \\
Sm100/75 & 1.83 & 13.18 \\
Sm150/25 & 1.58 & 12.69 \\
\hline
\end{tabular}

The addition of the CTAB salt increased the average pore diameter. The value found for sample Sm150/25 $(12.69 \mathrm{~nm})$ was smaller than for samples Sm50/75 $(13.04 \mathrm{~nm})$ and $\mathrm{Sm100/75}(13.18 \mathrm{~nm})$. This pattern can be explained by the decrease in $\mathrm{d}_{001}$ basal spacing, shown in Table 1 (XRD) and in Figure 3 (XRD), enabling the occurrence of saturation at exchange capacity of $100 \%$ of the CEC by the natural clay. The variation in average pore diameters results from the alteration of the basal spacing caused by the modification with CTAB salt. ${ }^{65}$

\section{Oil adsorption study}

Figure 4 shows the capacities for adsorption of oil from the contaminated saltwater for each of the adsorbents. In these tests, we used an initial oil concentration of $50 \mathrm{ppm}$ and different adsorbent masses $(0.1,0.3,0.7$ or $1.0 \mathrm{~g})$, at a temperature of $25^{\circ} \mathrm{C}$, rotation speed of $100 \mathrm{rpm}$ and time of $240 \mathrm{~min}$. The results show that the organophilic clays were better at removing oil than the untreated clay. This can be explained by the fact that organophilization enables the adsorption of organic compounds such as petroleum. Figure 4 also shows that the oil removal increased with rising adsorbent mass, and the best results were obtained with $1.0 \mathrm{~g}$ of the adsorbent. The oil removal rates with $1.0 \mathrm{~g}$ of adsorbent for all the samples are shown in Table 4. It can be seen that the removal rates of the three organophilic clays are very close to each other, with a small reduction 
for sample Sm150/25. This is related to the smaller average pore diameter and smaller surface area, as shown in Table 3.

The performance of the organophilic clays is even better than or comparable to other methods or adsorbents types. For example, the efficiency cited in literature is 90 , $90,93,78,86.58$, and $93.54 \%$, respectively, for catalytic oxidation, ${ }^{72}$ biological techniques, ${ }^{73}$ membranes, ${ }^{74}$ wool,${ }^{75}$ zeolite, ${ }^{38}$ and activated coal. ${ }^{6}$

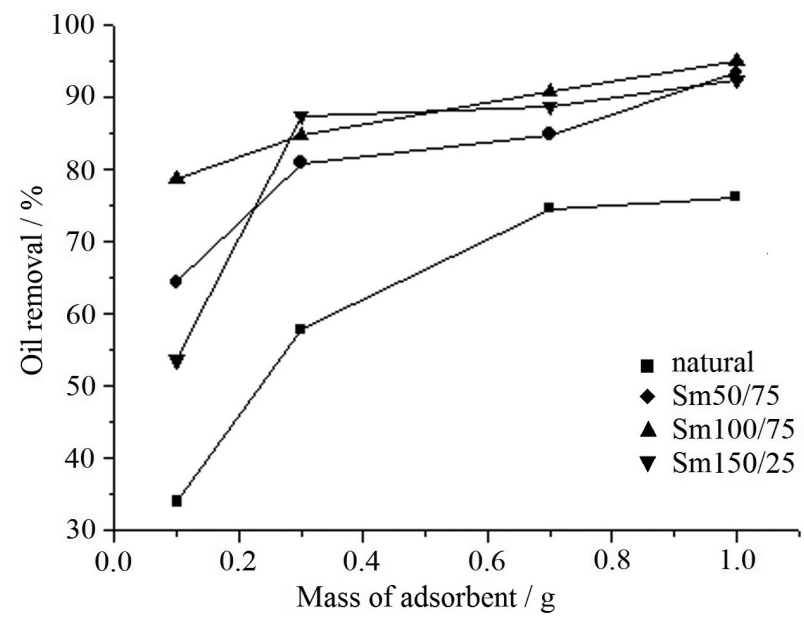

Figure 4. Oil removal capacity with different adsorbent masses. Conditions: $50 \mathrm{ppm}$ of oil, $25^{\circ} \mathrm{C}$, rotation of $100 \mathrm{rpm}$, contact time of $240 \mathrm{~min}$.

Table 4. Oil percentages removed with $1 \mathrm{~g}$ of adsorbent after contact for $240 \mathrm{~min}$

\begin{tabular}{lcccc}
\hline Sample & Natural & Sm50/75 & Sm100/75 & Sm150/25 \\
\hline Oil removed $/ \%$ & 76.16 & 93.45 & 94.98 & 92.40 \\
\hline
\end{tabular}

To determine the adsorption equilibrium time, the oil absorption percentages were studied in function of contact time, which varied from 15 to $240 \mathrm{~min}$, using $1.0 \mathrm{~g}$ of adsorbent and oil concentration in the saltwater of $50 \mathrm{ppm}$. The results are depicted in Figure 5. The percentage of oil removed increased with longer contact time. This behavior was more accentuated early in the process, and then became slower as time progressed. This can be explained by the fact that the number of voids available for adsorption declines as time progresses, so the oil removal capacity also diminishes.

Figure 5 shows that the adsorption equilibrium times of samples Sm50/75, Sm100/75 and Sm150/25 were 30, 180 and $120 \mathrm{~min}$, respectively; while for the natural clay the balance was reached at 180 minutes. The quantity of oil removed by the organophilic clays was greater than for the untreated clay after all the contact times, evidencing that organophilic clay obtained by treatment with CTAB is effective for oil removal.

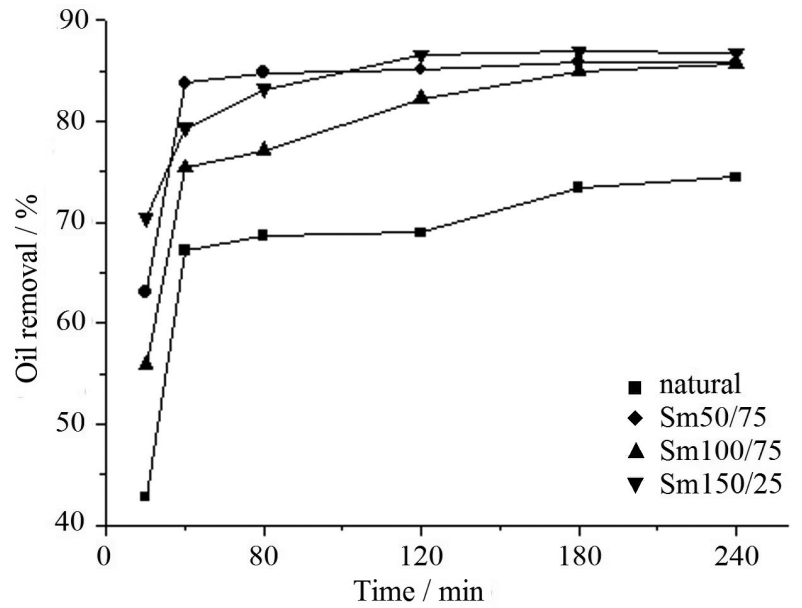

Figure 5. Oil removal capacity at different contact times. Conditions: $50 \mathrm{ppm}$ of oil, $25^{\circ} \mathrm{C}$, rotation of $100 \mathrm{rpm}, 1.0 \mathrm{~g}$ of adsorbent.

\section{Conclusions}

The characterization of the clay samples confirmed effective modification, based on the good oil removal rates of the organophilic clay samples. The XRD revealed a significant increase in the basal spacing of the modified clays in relation to the natural clay, evidencing the intercalation of the CTAB salt in the interlamellar structure of the clay and that this salt can accommodate different forms in the interlamellar region, enabling variation of the $\mathrm{d}_{001}$ basal spacing. The appearance of bands corresponding to the $\mathrm{CH}_{2}$ and $\mathrm{CH}_{3}$ supplied by the quaternary ammonium salt (FTIR spectra), the greater mass loss in the region corresponding to organic compounds (TG) and the reduced surface area and average pore diameters of the organophilic clays confirmed the presence of the surfactant CTAB and thus the organophilization of the clay.

The organophilic clays were better at removing oil than the untreated clay, with rates of $93.45,94.98$ and $92.40 \%$ for samples Sm50/75, Sm100/75 and Sm150/25, respectively. Even the untreated clay was relatively effective in removing oil $(76.16 \%)$. All told, the results indicate the outstanding potential of the smectite clay studied in removing oil from contaminated effluents, especially after organophilization, with the added advantage of low cost of the clay due to its plentiful availability.

\section{Acknowledgments}

We thank the Labs Analysis and Research of Food, Beverage and Environmental (IFMA); the Analytical Materials Center and the Analytical Center (UFMA); to the Nucleus of Catalysis (UFRJ) and to the Interdisciplinary Laboratory for Advanced Materials (UFPI), for conducting 
the analyses. E. F. Lucas thanks CNPq, FAPERJ and Petrobras.

\section{References}

1. Scanlon, J.; J. Hazard. Mater. 2001, 86, 121.

2. Pottmaier, D.; Melo, C. R.; Sartor, M. N.; Kuester, S.; Amadio, T. M.; Fernandes, C. A. H.; Marinha, D.; Alarcon, O. E.; Renewable Sustainable Energy Rev. 2013, 19, 678.

3. Karhu, M.; Kuokkanen,T.; Rämö, J.; Mikola M.; Tanskanen, J.; J. Environ. Manage. 2013, 128, 413.

4. https://www.iea.org/oilmarketreport/omrpublic/, accessed in May 2016.

5. Fakhru'l-Razi, A.; Pendashteh, A.; Abdullah, L. C.; Biak, D. R. A.; Madaeni, S. S.; Abidin, Z. Z.; J. Hazard. Mater. 2009, 170,530 .

6. Okiel, K.; El-Sayed, M.; El-Kady, M. Y.; Egypt. J. Pet. 2011, 20,9 .

7. https://www.epa.gov/oil-spills-prevention-and-preparednessregulations, accessed in May 2015.

8. Wake, H.; Estuarine, Coastal Shelf Sci. 2005, 62, 131.

9. Alfaro, M. A. Q.; Ferro, S.; Martínez-Huitle, C. A.; Vong, Y. M.; J. Braz. Chem. Soc. 2006, 2, 227.

10. Guerra, D. L.; Santos, M. R. M. C.; Airoldi, C.; J. Braz. Chem. Soc. 2009, 4, 594.

11. Diya'uddeen, B. H.; Daud, W. M. A. W.; Aziz, A. R. A.; Process Saf. Environ. Prot. 2011, 89, 95.

12. Guimarães, J. R.; Gasparini, N. C.; Maniero, M. G.; Mendes, C. G. N.; J. Braz. Chem. Soc. 2012, 9, 1680.

13. Moazed, H.; Viraraghavan, T.; J. Can. Pet. Technol. 2001, 40, 37.

14. Ko, C. H.; Fan, C.; Chiang, P. N.; Wang, M. K.; Lin, K. C.; J. Hazard. Mater. 2007, 149, 275.

15. Aivalioti, M.; Papoulias, P.; Kousaiti, A.; Gidarakos, E.; $J$. Hazard. Mater. 2012, 207-208, 117.

16. Nourmoradi, H.; Nikaeen, M.; Khiadani, H. M.; Chem. Eng. J. 2012, 191, 341.

17. Silva, C. M. F.; Barros, C. C.; Queirós, Y. G. C.; Marques, L. R. S.; Louvisse, A. M. T.; Lucas, E. F.; Chem. Chem. Technol. 2012, 6, 415 .

18. Sharma, A. K.; Lee, B.; J. Environ. Manage. 2013, 128, 787.

19. Simplicio, S.; Santa Maria, L. C.; Costa, M. A. S.; Lucas, E. F.; Queirós, Y. G. C.; Marques, L. R. S.; Costa L. C.; Hui, W. S.; Silva, M. R.; Polímeros 2013, 23, 590.

20. Aversa, T. M.; Queirós, Y. G. C.; Lucas, E. F.; Polímeros 2014, $24,45$.

21. Li, D.; Kaplan, D. I.; Knox, A. S.; Crapse, K. P.; Diprete, D. P.; J. Environ. Radioact. 2014, 136, 56.

22. Silva, C. M. F.; Rocha, Q. C.; Rocha, P. C.; Louvisse, A. M. T.; Lucas, E. F.; J. Environ. Manage. 2015, 157, 205.

23. Churchmann, G. J.; Appl. Clay Sci. 2001, 21, 177.
24. Mansur, C. R. E.; Oliveira, R. S.; Akeda, V.; Queirós, Y. G. C.; Spinelli, L. S.; Lucas, E. F.; J. Appl. Polym. Sci. 2012, 123, 218.

25. Alther, G.; Filtr. Sep. 2008, 45, 22.

26. Chen, X.; Hong, L.; Xu, Y.; Ong, Z. W.; ACS Appl. Mater. Interfaces 2012, 4, 1909.

27. Sidik, S. M.; Jalil, A. A.; Triwahyono, S.; Adam, S. H.; Satar, M. A. H.; Hameed, B. H.; Chem. Eng. J. 2012, 203, 9.

28. Ahmaruzzaman, M. D.; Adv. Colloid Interface Sci. 2008, 143 , 48.

29. Paiva, L. B.; Morales, A. R.; Valenzuela-Diaz, F. R.; Appl. Clay Sci. 2008, 42, 8.

30. Espantaleón, A. G.; Nieto, J. A.; Fernández, M.; Marsal, A.; Appl. Clay Sci. 2003, 24, 105.

31. Ijagbemi, C. O.; Baek, M. H.; Kim, D. S.; J. Hazard. Mater. 2009, 166, 538 .

32. Moazed, H.; Viraraghavan, T.; Energy Sources, Part A 2005 , 27, 101.

33. Costa Filho, A. P.; Gomes, A. S.; Lucas, E. F.; Polímeros 2005 , 15, 212.

34. Mirmohamadsadeghi, S.; Kaghazchi, T.; Soleimani, M.; Asasian, N.; Appl. Clay Sci. 2012, 59-60, 8.

35. Odom, I. E.; Philos. Trans. R. Soc., A 1984, 311, 391.

36. Murray, H. H.; Appl. Clay Sci. 2000, 17, 207.

37. Silva, A. R. V.; Ferreira H. C.; Revista Eletrônica de Materiais e Processos 2008, 3, 26.

38. Barbosa, R.; Morais, D. D. S.; Araújo, E. M.; Mélo, T. J. A.; Cerâmica 2012, 58, 495.

39. Rodrigues, M. G. F.; Cerâmica 2008, 49, 152.

40. Coelho, A. C. V.; Santos, P. S.; Quim. Nova 2007, 30, 146.

41. Menezes, R. R.; Ávila Jr, M. M.; Santana, L. N. L.; Neves, G. A.; Ferreira, H. C.; Cerâmica 2008, 54, 152.

42. Iturri, L. A.; Buschiazzo, D. E.; Catena 2014, 121, 81.

43. Hongping, H.; Lingya, M.; Jianxi, Z.; Ray, L. F.; Benny, K. G. T.; Faïza, B.; Appl. Clay Sci. 2014, 100, 22.

44. Chatterjee, A.; Ebina, T.; Onodera, Y.; Mizukami, F.; J. Chem. Phys. 2004, 120, 3414.

45. Cerri, G.; Langella, A.; Pansini, M.; Cappelletti, P.; Clays Clay Miner. 2002, 50, 127.

46. Su-Lin, H.; Juang R.-S.; J. Environ. Manage. 2009, 90, 1336.

47. Jincheng, W.; Xiaoyu, Z.; Wenli, H.; Nan, X.; Xingchen, P.; Powder Technol. 2012, 221, 80.

48. Mehlich, A.; Soil Sci. 1948, 66, 429.

49. Brunauer, S.; Emmett, P. H.; Taylor, E.; J. Am. Chem. Soc. 1938, 60, 309

50. Barret, E. P.; Joyner, L .G.; Halenda, P. P.; J. Am. Chem. Soc. 1951, 73, 373.

51. Santos, P. S.; Ciências e Tecnologias das Argilas, $2^{\mathrm{a}}$ ed., vol. 3; Edgard Blucher: São Paulo, Brazil, 1992.

52. Guarino, A. W. S.; San Gil, R. A. S.; Polivanov, J.; Menezes, S. M. C.; J. Braz. Chem. Soc. 1997, 6, 581. 
53. Carvalho, M. N.; Motta, M.; Benachour, M.; Sales, D. C. S.; Abreu, C. A. M.; J. Hazard. Mater. 2012, 239-240, 95.

54. Villar, M. V.; Gómez-Espina, R.; Gutiérrez-Nebot, L.; Appl. Clay Sci. 2012, 65-66, 95.

55. Odom, I. E.; Philos. Trans. R. Soc., A 1984, 311, 391.

56. Nilgün, Y.; Cengiz, B.; Mü erref, Ö.; Yüksel, S.; Appl. Surf. Sci. 2012, 258, 2534.

57. Wu, S.; Zhang, Z.; Wang, Y.; Liao, L.; Zhang, J.; Mater. Res. Bull. 2014, 59, 59.

58. Lopes, C. W.; Penha, F. G.; Braga, R. M.; Melo, D. M. A.; Pergher, S. B. C.; Petkowicz, D. I.; Quim. Nova 2011, 34, 1152.

59. Yu, W. H.; Ren, Q. Q.; Tong, D. S.; Zhou, C. H.; Wang, H.; Appl. Clay Sci. 2014, 97-98, 222.

60. Delbem, M. F.; Valera, T. S.; Valenzuela-Diaz, F. R.; Demarquette, N. R.; Quim. Nova 2010, 33, 309.

61. Zhengwen, H.; Gaohong, H.; Yuanfa, L.; Chunxu, D.; Xuemei, W.; Wei, Z.; Appl. Clay Sci. 2013, 75-76, 134.

62. Wei, H. Y.; Qian, Q. R.; Dong, S. T.; Chun, H. Z.; Wang, H.; Appl. Surf. Sci. 2014, 97-98, 222.

63. Gammoudi, S.; Frini-Srasra, N.; Srasra, E.; Appl. Clay Sci. 2012, 69, 99.

64. Zhou, Y.; Jin, X. Y.; Lin, H.; Chen, Z. L.; Chem. Eng. J. 2011, $166,176$.

65. Gámiz, B.; Celis, R.; Hermosín, M. C.; Cornejo, J.; Johnston, C. T.; Appl. Clay Sci. 2012, 58, 8.
66. Scholtzová, E.; Tunega, D.; Madejová, J.; Pálková, H.; Komadel, P.; Vib. Spectrosc. 2013, 66, 123.

67. Silverstein, R.; Webster, F. X.; Kiemle, D.; Silverstein, R. M.; Spectrometric Identification of Organic Compounds, $7^{\text {th }}$ ed.; Wiley: New York, USA, 2005.

68. Xi, Y.; Martens, W.; He, H.; Frost, R. L.; J. Therm. Anal. Calorim. 2005, $81,91$.

69. Lv, G.; Chang, P. H.; Xing, X.; Jiang, W. T.; Jean, J. S.; Li, Z.; Arab. J. Chem. in press. DOI: 10.1016/j.arabjc.2015.04.016.

70. Vazquez, A.; López, M.; Kortaberria, G.; Martín, L.; Mondragon, I.; Appl. Clay Sci. 2008, 41, 24.

71. Mrad, I.; Ghorbel, A.; Tichit, D.; Lambert, J. F.; Appl. Clay Sci. 1997, 12, 349.

72. Adams, M.; Campbell, I.; Robertson, P. K. J.; Int. J. Photoenergy 2008, 2008, 1.

73. Jou, C. J. G.; Huang, G. C.; Adv. Environ. Res. 2003, 7, 463.

74. Rahman, M. M.; Al-Malack, M. H.; Desalination 2006, 191, 16.

75. Rajakovic, V.; Aleksic, G.; Radetic, M.; Rajakovic, L.; J. Hazard. Mater. 2007, 143, 494.

Submitted: February 8, 2016

Published online: May 31, 2016 